\title{
İstanbul'un İlk Verem Savaşımı Derneği: Ligue contre la Tuberculose (Phitisie pulmonaire) de Constantinople
}

\section{The First Anti-Tuberculosis Society in Istanbul: Ligue contre la Tuberculose (Phitisie pulmonaire) de Constantinople}

\author{
Şeref Etker ${ }^{1}$ (1)
}

'Dr., İstanbul, Türkiye

ORCID: Ş.E. 0000-0001-6966-8816

Sorumlu yazar/Corresponding author: Şeref Etker,

Istanbul, Türkiye

E-posta/E-mail: serefetker@gmail.com

Başvuru/Submitted: 05.09.2019

Revizyon Talebi/Revision Requested:

18.10.2019

Son Revizyon/Last Revision Received: 28.10.2019

Kabul/Accepted: 04.11 .2019

Online Yayın/Published Online: 03.07.2020

Atıf/Citation: Etker, Şeref. “istanbul'un ilk Verem Savaşımı Derneği: Ligue contre la Tuberculose (Phitisie pulmonaire) de Constantinople." Osmanlı Bilimi Araştırmaları 21, 2 (2020): 225-247. https://doi.org/10.26650/oba.710116

\section{öz}

İstanbul ve çevresinde verem savaşımı için 1903 yılında Ligue contre la Tuberculose (Phitisie pulmonaire) de Constantinople adiyla bir dernek kurulmuştur. Dr. Kleovulos H. Kokolatos (Cléobule C. Coccolatos, 1865-1944) tarafından kurulan bu dernek, 1912 yılında Société internationale contre la Tuberculose de Constantinople adını almıştır. Böylece, I. Dünya Savaşı́nın sonunda kurulan Veremle Mücadele Osmanlı Cemiyeti'nden önce, İstanbullu hekimlerin Vereme (Fitizi Pulmoner, Akciğer Tüberkülozu) Karşı Savaşım Birliği'ni oluşturarak Türkiye'nin öncü sağlık örgütleri arasına katılıkları saptanmaktadır. Kleovulos Kokolatos, aynı yıllarda ayrıca Bulletin médical de Constantinople adlı aylık bir dergi yayımlamıştır. Derneğin 1903 ve 1912 tarihli tüzüklerinde, din, milliyet ve cinsiyet ayrımı yapılmadan İstanbul halkına veremden korunma çarelerini öğretme, yoksul hastalara parasız sağlık hizmeti sunma, dispanser ve sanatoryumlar kurma amaçları öne çıkmaktadır. Dernek üyeleri, özellikle tüberküloz hastalığının erken tanısı, sağaltımı ve genel hijyen uygulamaları eğitiminde başarı sağlamış görünmektedir. Dr. Kleovulos Kokolatos'un yirminci yüzyılın başında tüberküloza karşı başlattığı uluslararası savaşım Türkiye'nin verem savaş derneklerine örnek olmuştur.

Anahtar sözcükler: Tüberküloz, verem, sağlık dernekleri, tüzük, Türkiye, tıp tarihi, Kleovulos Kokolatos, Cléobule C. Coccolatos

\section{ABSTRACT}

The Ligue contre la Tuberculose (Phitisie pulmonaire) de Constantinople convened in 1903 with the objective of combating tuberculosis in Istanbul and its environs. Established by Dr. Kleovulos H. Kokolatos (Cléobule C. Coccolatos, 1865-1944), a native internist, the League was reorganized as the Société internationale contre la Tuberculose de Constantinople in 1912. The League became the first medical association in the combat against tuberculosis in Istanbul. An Ottoman antituberculosis Society was established in 1918. Dr. C. Coccolatos also published the monthly Bulletin médical de Constantinople. The regulations of the Society from 1903 and 1912 stipulated non-discrimination with regard to religion, ethnicity and gender, in offering instruction towards 
tuberculosis prevention, dispension of free healthcare and the creation of sanatoriums in the capital. The members of the Society succeeded in raising awareness of the contagion of tuberculosis and implementation of hygiene measures. Cléobule / Cleovoulos Coccolatos' pioneering association constituted a model for anti-tuberculosis societies in Turkey.

Keywords: Tuberculosis, phitisie, medical society, regulation, Turkey, history of medicine, Kleovulos Kokolatos, Cléobule C. Coccolatos 
Türkiye'de verem hastalığına karşı örgütlenmenin Birinci Dünya Savaşının son yılında kurulan Veremle Mücadele Osmanlı Cemiyeti (VMOC) ile başladığı varsayılır. ${ }^{1}$ Oysa, VMOC'nden onbeş yıl kadar önce, ${ }^{2} 1903$ yılında Dr. Kleovulos Kokolatos'un öncülüğünde, İstanbul'da "Tüberküloza (Fitizi Pulmoner) Karşı Savaşım Birliği” Ligue contre la Tuberculose (Phitisie pulmonaire) de Constantinople (LCTC) adıyla kurulmuş bir başka dernek vardır. ${ }^{3}$ Dr. Kokolatos ile birlikte derneğin tüzüğünü hazırlayanlar arasında: Dr. Leonidas Limarakis, Dr. Vasil Ritzo (Vasileos Ritsos) ile Dr. Nikolaos Fermanoğlu'nun adları bilinmektedir. Kleovulos Kokolatos'un kurucu başkanlığını yaptığı Birliğin genel sekreteri Eczac1-Kimyager Pierre Apéry (Petros Aperis)'dir.

LCTC, ilk toplantısını 27 Eylül 1903 Pazar günü Cemiyet-i Tıbbiye-i Şahane'nin Beyoğlu'ndaki lokalinde yaparak Yönetim Kurulunu belirlemiştir: ${ }^{4}$

Dersaadet'de verem hastalığına karşı ittihaz-1 tedbir etmek üzre bir heyet-i tıbbiye teşkilini tasavvur eden doktorlar evvelki gün Cemiyet-i Tibbiye-i Şahane'de akd-i ictima ile Doktor [Kleovulos] Kokolatos'u riyasete, Doktor İstekulis [Konstandinos Stekulis] ile Doktor [Viçen] Ormanyan'1 riyaset-i saniyeye ve Aperi [Apéry] Efendi'yi heyetin hizmet-i kitabetine ve şehrimizin etibbasından on kadar zevatı da muhasebe ve vezne memurluklarile müşavirliğe tayin etmişlerdir.

1 Tevfik İsmail Gökçe, Verem Savaşında 50 Yll, $1918-1968$ (İstanbul: Türkiye Ulusal Verem Savaş1 Derneği, 1968); Ekrem Kadri Unat, "Osmanlı İmparatorluğunun Son 40 Y1lında Türkiye'nin Tüberküloz Tarihçesi Üzerine," [İstanbul Üniversitesi] Cerrahpaşa Tip Fakültesi Dergisi 10, 4 (1979): 273-284; Saim Polat Bengiserp, "Türkiye'de Sanatoryum ve Göğüs Hastalıkları Hastanelerinin Tarihine Bir Bakış," IV. TürkTpp Tarihi Kongresi, İstanbul, 18-20Eylül 1996, KongreyeSunulanBildiriler(Ankara:TürkTarih Kurumu, 2003) içinde, 157-186; Murat Aksu, "Tıp Tarihi Açısından Türkiye'de Veremle Savaş" (Tıpta Uzmanlık Tezi, Ankara Üniversitesi Tıp Fakültesi Deontoloji AD, 2006); Murat Aksu, Tip Tarihi Açısından Türkiye'de Verem Savaşı (Ankara: Türkiye Ulusal Verem Savaşı Dernekleri Federasyonu, 2007); Ceren Gülser İlikan (Rasimoğlu), "Tuberculosis, Medicine and Politics: Public Health in the Early Republican Turkey" (Yüksek Lisans Tezi, Boğaziçi Üniversitesi Atatürk İlkeleri ve İnkılap Tarihi Enstitüsü, 2006); Asuman Tezcan, "Savaş Yıllarında İstanbul ve Anadolu'da Verem," Bilgi ve Bellek say1 5 (Kış 2006): 105-121; Murat Aksu ve Sadık Toprak, "The Importance of Associations in the Struggle against Tuberculosis in Turkey," Tüberküloz ve Toraks 60, 3 (2012): 291-294; Nuran Yıldırım, "Osmanlı Devleti’nde Göğüs Hastalıkları ve Verem," Türk Gögü̈s Hastallkları Tarihi, ed. Muzaffer Metintaş (İstanbul: Türk Toraks Derneği, Aves Yayıncılık, 2012) içinde, 35-36; Nuran Yıldırım ve Mahmut Gürgan, "Verem Mücadele Cemiyetleri/Verem Savaş Dernekleri," aynı yerde, 85-100; Léa Delmaire, "Construction et déconstructions d'une maladie sociale. Les politiques de lutte contre la tuberculose en Turquie (1948-1960)" (Yüksek Lisans Tezi, Institut d’Études Politiques de Paris, 2017).

2 Veremle Mücadele Osmanll Cemiyeti Nizamname-i Esasisi ([İstanbul]: Bahriye Matbaas1, 1918/1334), $14.5 \times 21.0$ cm., 18 s. Cemiyetin adresi: Cağaloğlu, Mahmudiye Caddesi'nde Cemiyet-i Hayriye-i İslamiye binasının üst katı.

3 "Règlement de la Ligue contre la Tuberculose (Phitisie pulmonaire) de Constantinople (14/27 Septembre 1903)," Revue médico-pharmaceutique (İstanbul) 17 (1904): 42-44. Yeni (Gregoriyen) ve eski (Jülyen) tarihler birlikte verilmiştir.

4 Sabah, numero 5003, 7 Receb 1321/16 Eylül 1319/29 Eylül efrenci 1903, 3. 


\section{Dr. Kleovulos Hristos Kokolatos (Cléobule Chr. Coccolatos / K $\lambda$ \&óßov $\lambda$ os}

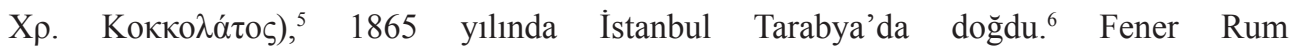
Mekteb-i Kebiri'nden 9 Haziran 1885 tarihinde mezun oldu, ${ }^{7}$ ardindan Yunanistan'a giderek Atina Üniversitesi'nin Tip Fakültesi'ne kaydoldu (11 Kasım 1885). ${ }^{8}$ Bu Fakülteden 1891 yılında Tıp Doktoru derecesiyle mezun olan Kleovulos Kokolatos, öğrenciliği sırasında yayıncılık yaptı: Önce bir takvim-almanak, ${ }^{9}$ daha sonra Akademiya ${ }^{10}$ ve Iatrikon Deltion (tis Akademias) ${ }^{11}$ dergilerini yayımladı. ${ }^{12}$

Dr. Kokolatos, 1891 'de İstanbul'a döndükten sonra, Beyoğlu'na yerleşti, muayenehanesini açtı ve Elen Filoloji Derneği'ne (Ellinikos Filologikos Syllogos: Rum Cemiyet-i Edebiyesi) üye oldu; Derneğin antropoloji, biyoloji ve bilim kurullarında görev aldı. Kleovulos Kokolatos'un 1894'te Fransa'ya gittiği, ${ }^{13}$ Paris hastanelerinde çalışırken Paris Anatomi Derneği'ne (Société anatomique de Paris) üye olduğu ve geliştirdiği basit bir tıbbi aletle (aspiratör) Lyon'da katıldığı uluslararası sergide mansiyon kazandığı bilinmektedir. ${ }^{14}$

5 Коккода́ Kokolatos'dur ve dönemin Türkçe metinlerine Kokolatos olarak geçmiştir, bkz. aşağıda dn. 41 ve 42.

6 Kleovulos Hristos Kokolatos’un doğum/vaftiz kayıtlarına ulaşılamamıştır. Atina Üniversitesi arşivindeki kayıt defterinde (sıra no. 3352) Tıp Fakültesine girdiği 1885 yılında 20 yaşında olduğu belirtilmektedir. Aynı yerde memleketi Keffalinia (Kefalonya adası) olarak gösterilmiştir. Kleovulos Kokolatos, özgeçmişinde Tarabya doğumlu olduğunu belirtir, bkz. Türkiye Teracimi Ahval Ansiklopedisi / Encyclopédie biographique de Turquie, c.2, haz. Mehmet Zeki [Pakalın] (İstanbul: Ekspres Matbaas1, 1929), 322. Dr. Kleovulos Kokolatos'un babası Hristos Kokolatos'un Tarabya Rum Ortodoks kabristanında bulunan mezarında doğum yeri Kefalonya olarak gösterilmiştir. Ailenin Kefalonya'dan İstanbul'a göç ettiği, Dr. Kleovulos H. Kokolatos ile kardeşi Dr. Nikolaos H. Kokolatos'un İstanbul'da doğdukları anlaşılmaktadır.

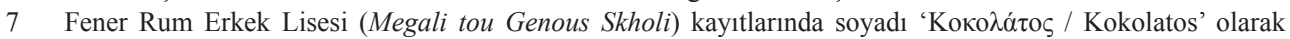

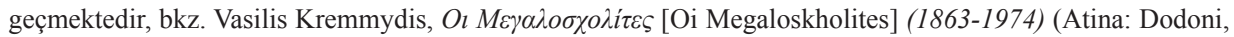
2007), 72. Aynı yerde, Kleovulos Kokolatos (ailesi) ‘Kefalonyalı' olarak gösterilmektedir. Kleovulos Kokolatos ilköğrenimine Tarabya'daki Zarifion okulunda başlamış olmalıdır. Dr. Kokolatos daha sonra mezunu olduğu Fener'deki okulunun tabipliğini yapacaktır.

8 Atina Üniversitesi arşivindeki bilgiye göre, Kleovulos Kokolatos'a İstanbullu mimar Akhilleas Kampanakis

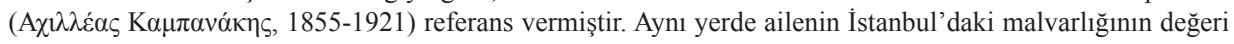
"20.000 drahmi” olarak gösterilmiştir.

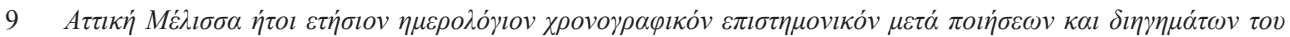
Étovৎ 1887 [Attiki Melissa itoi etision imerologion khronografikon epistimonikon meta poiseon kai diigimaton tou etous 1887] birinci y1l (Atina: Vlastou Varvarrigou, 1886).

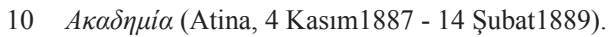

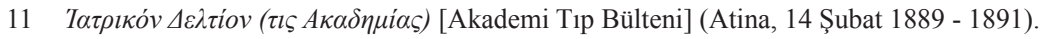

12 Kleovulos Kokolatos, Fener Lisesi'nden mezun olurken de "Genç Müzler/Musalar" adlı bir derleme

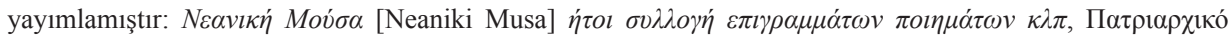

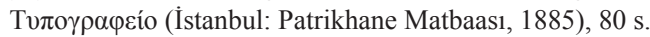

13 Gazete ilanlarında "Doktor Kokolatos Efendi Paris şehrinde ikmal-i tahsil etdikden sonra müddet-i medide şehr-i mezkur hastahanelerinde istihdam ile ameliyat-1 mahsusa ve bilhassa emraz-1 dahiliye... hastalıklarının tedavisinde kesb-i ihtisas eylemişdir" denmiştir.

14 Bulletin officiel de l'Exposition de Lyon, universelle, internationale et coloniale no. 40 (4 octobre 1894): 3 (Médecine et Chirurgie: Diplôme de Mention honorable). "Une nouvel aspirateur, disposé pour aspirer et injecter du Dr. Coccolato, approuvé par l'Académie de Médecine de Paris, Séance de 6 Novembre 1894,

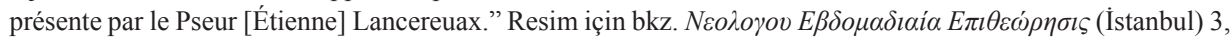
51 (6 Kasım 1894), 1008. http://pleias.lis.upatras.gr/index.php/neologou/article/view/28574/28557 


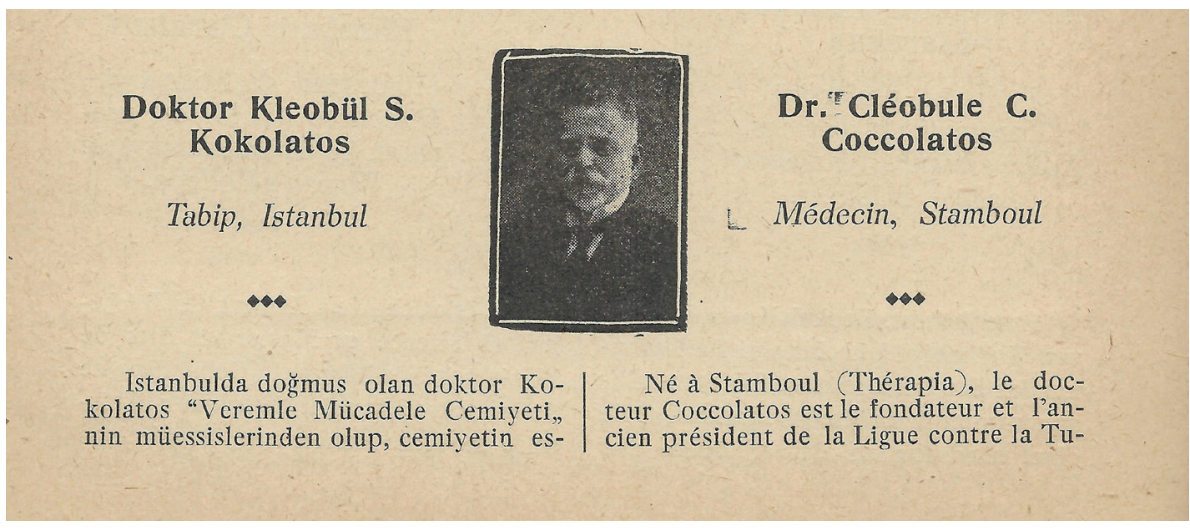

Dr. Kleovulos Hristos Kokolatos (1865-1944)

İstanbul "Veremle Mücadele Cemiyeti” kurucusu ${ }^{15}$

Dr. Kleovulos Kokolatos, 1895 'te Louis Pasteur'ün ölümü ve Röntgen 1şınlarının bulunuşu üzerine Syllogos'ta iki konferans verdi:

Pasteur, hayatı ve eserleri [Pasteur, vios kai erga]

Röntgen - X ışınlarının teorik, tarihsel ve pratik yönleri (deneylere dayanarak)

[Peri ton aktinon tou X-Roentgen ipo theoritikin, istorikin kai praktikin epopsin (meta peiramaton)]

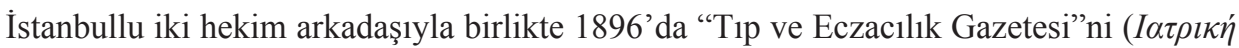

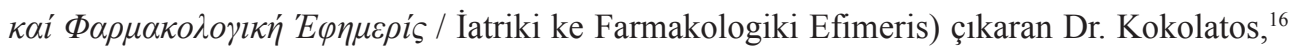
aynı yıl içinde, Atina Üniversitesi'nde öğretmeni olan Dr. Theodoros Afenduli'nin yaşamı ve bilimsel çalışmalarıyla ilgili bir yayın yaptı. ${ }^{17}$ Kendisi gibi Tarabyalı olan Dr. Spiridon Mavroyeni Paşa'nın ölümü üzerine biyografisini hazırlayarak 11 Mart 1902'de Syllogos'ta sunduktan sonra Atina' da yayımladi. ${ }^{18}$

15 “Dr. Klebül S. Kokolatos / Dr. Clébule S. Coccolatos," Türkiye Teracimi Ahval Ansiklopedisi / Encyclopédie biographique de Turquie, c.2, haz. Mehmet Zeki [Pakalın] (İstanbul: Ekspres Matbaas1, 1929), 322-323 (portre). Kleovulos Kokolatos’un baba (göbek) adı Hristos, Fransızca metinde C.(hristos) olarak kısaltılmış; C. harfinin Fransızca okunuşu S. olarak Türkçe yazımına yanlış geçmiştir.

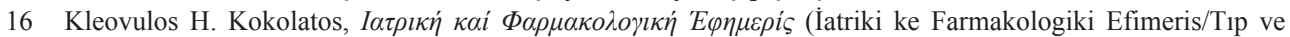

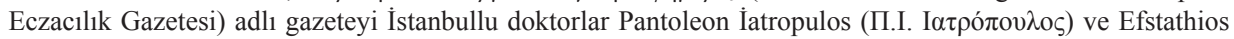

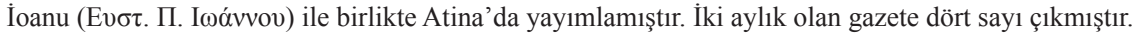

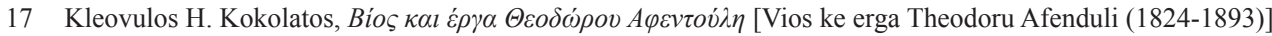
(İstanbul: I. Pallamari, 1896), 7 s.

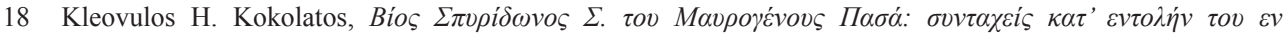

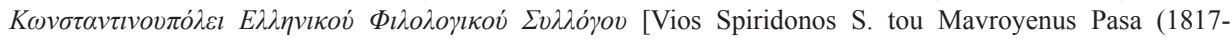
22 Ocak 1902)] (Atina: Anesti Konstantinidi, 1902), 24 s. 
Dr. Kleovulos Kokolatos, Cemiyet-i Tıbbiye-i Şahane’ye (CTŞ) 1905 yılında üye seçildi. Bir yıl sonra, Cemiyet'in kalp hastalıkları konusunda yapılan en başarılı çalışmaya verdiği “Amélie Apéry Ödülü’nü aldı. Cemiyet-i Tıbbiye-i Şahane’nin 50. kuruluş yıldönümü için düzenlenen bilimsel toplantılarda lepra ve deri hastalıklarındaki gelişmeler üzerine hazırladığg kapsamlı ve tartışmalı sunum onun mesleki ilgi alanlarının genişliğini gösterir. ${ }^{19} \mathrm{CTŞ}$ yönetimlerinde uzun sürelerle "Kütüphaneci” (bibliothécaire) ve Genel Sekreter olarak görev ald1. ${ }^{20}$

Şehremaneti'nin Hıfzıssihha Komisyon-1 Âlisi'ne 1901 yilında atanan Dr. Kleovulos Kokolatos burada mortalite istatistiklerini inceleme olanağını buldu. ${ }^{21}$ Sosyal ve yaratıcı bir hekim olan Kokolatos, çağdaş tıp dallarının gelişmesini izleyerek meslektaşlarını Ligue contre la Tuberculose (Phitisie pulmonaire) de Constantinople içinde bir araya getirmeyi başardı. ${ }^{22}$ Şehremaneti Sihhiye Dairesi'nin istatistiklerine göre, bu Birliğin kurulduğu 1903 yılında, İstanbul'da kayıtlara geçen 14.136 ölümün \% 19’u verem hastalığının sonucudur. Bu gruptaki ölümlerin \% 74’ü akciğer tüberkülozuna (phitisie pulmonaire: edranü'r-rie) bağlıdır. ${ }^{23}$ Verem ölümleri ise kamuoyuna genellikle yansitılmamaktadir. ${ }^{24}$

19 Cléobule C. Coccolatos, "Rapport sur les travaux de dermatologie présentés à la Société Impériale de Médecine pendant son premier Cinquantenaire (1856-1906)," Dersaadet Cemiyet-i Tibbiye-i Şahane'nin Ellinci Sene-i Devriyesi (1856-1906)/Cinquantenaire de la Société Impériale de Médecine de Constantinople (1856-1906) (Constantinople: Imp. L. Babok \& Fils, 1907) içinde, 191-235 (lu dans les séances du 26 Avril et du 10 Mai 1907).

20 Cléobule Ch. Coccolatos, Historique de la Bibliothéque de la Société Impériale de Médecine de Constantinople, 1857-1913 (Istanbul: Imprimerie Chanth, 1913), 39 s.

21 T. C. Cumhurbaşkanlığı Devlet Arşivleri Başkanlığı Osmanlı Arşivi (BOA) İ.ŞE.00014.00037.001, 7 Teşrinisani 1317/20 Kasım 1901.

221901 yllında Berlin'de l'Association internationale contre la Tuberculose, Yunanistan'da "Pan-Elenik antiTübeküloz Derneği” (П Dr. Constantin Simionesco da 1902'de Fransa'da l'Euvre antituberculeuse de Paris adını verdiği bir dernek kurdu. Kifidis, Dr. Kokolatos'un l'Association internationale contre la Tuberculose derneğinin muhabir üyesi olduğunu bildirmektedir, bkz. aşağıda dn. 41.

23 [Şehremaneti Sıhhiye Dairesi] “İstanbul Şehrinin Yirmi Senelik Verem Vefiyat İstatistiği (1315/18991335/1919)," Hüsameddin Şerif [Kural]. Verem Teşhis ve Tedavisi ([İstanbul]: Mekteb-i Trbbiye-i Şahane Matbaası, 1337/1921) içinde, 9-10.

24 “Dersaadet'de vefiyat: 14 Eylülden 20 Eylüle [1903] kadar 180 vefat vuku bulmuşdur. Bunlardan 2'si kızıl, 2'si çiçek, 11'i tifodan vuku bulub diğeri adi hastalıklarındandır." Malumat, aded 2288, 30 Cemaziyülahir 1321/9 Eylül rumi 1319/22 Eylül efrenci 1903, s. 2, st. 5. 


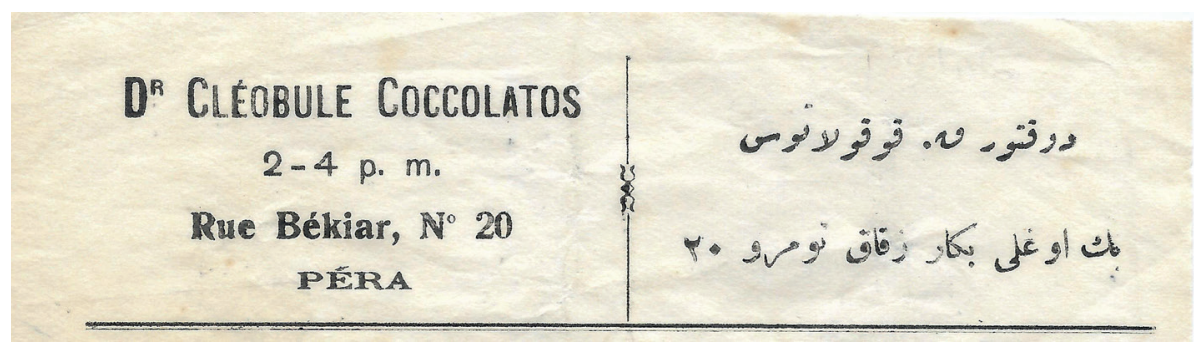

Dr. K. Kokolatos'un reçete başlığı: Beyoğlu Bekâr sokak, numero $20{ }^{25}$

Dr. Kokolatos'un verem konusunda yalnız Beyoğlu'nda Syllogos'ta verdiği konferanslar bilinmektedir. Halkı ve hekimleri ilgilendiren benzer konularda başka ortamlarda da konuşmalar yapmış olmalıdır:26

\section{0-1901}

Veremden korunma [Profilaksis apo tis fthiseos, Vosporis (İstanbul), May1s 1901]

\section{1-1902}

Bugünün Avrupa'sında vereme karşı savaşın nasıl yürütüldüğüne dair

[Pos tin simeron en Evropi dieksagetai o kata tis fthiseos agon]

\section{2-1903}

Tüberküloza yatkın kişilerin hijyeni hakkında [Peri tis igieinis ton prodiatetheimenon is tin fthisin]

İstanbul'daki Verem Savaş Derneği [LCTC] tarafından: Sanatoryumlar ve burada uygulanan verem tedavileri hakkında

[Ek merous ton en Konstantinupoli sindesmou kata tis fimatioseos. Peri fthisiatreion (sanataorion/sanatoriumes) kai tis therapies tis fimatioseos en autes]

Sanatoryumların kurulması gerekli mi? [Inai anangaia kai par imin i idrisis fthisiatreion]

Veremli hasta evde nasil tedavi edilir? [Pos prepei na therapevetai ofthisikos kat oikon]

25 Dr. K. Kokolatos’un diğer adresleri: Sakızağacı (Ağa Cami/Atıf Yılmaz) sokak no. 6, Sakızağacı sokak no. 32, Sakızağacı sokak no. 68, Abanos (Abanoz/Halas) sokak no. 6, Abanos sokak no. 36, Tarlabaşı, no. 164. Dr. Kleovulos Kokolatos, "On yıldır göğüs ve mide hastalıklarına bakmaktadır. Hastalarını sadece evinde

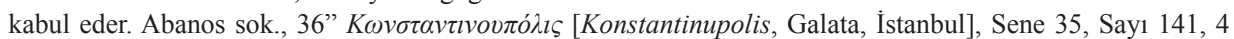
Temmuz 1901, s. 3, st. 4. Derneğin adresi Dr. Kokolatos’un bu evi olmalıdır. "Dr. K1. Kokkolatos," erişim 15.03.2020, https://srv-web1.parliament.gr/main.asp?current=8259664

Başka bir ilanda: "Çeharşembe ve Cuma günleri saat dörtden altıya kadar Bab-1 ali caddesinde Meserret Apartmanı tahtındaki İbrahim Nazif Efendinin Eczahanesinde bulunur” Sabah, numero 5050, 25 Şaban 1321/2 Teşrinisani 1319/15 Teşrinisani efrenci 1903, s. 4, st. 5.

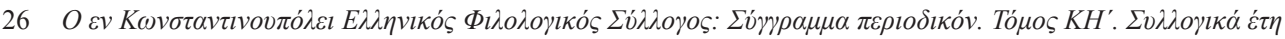

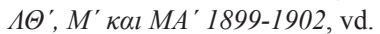




\section{3-1904}

Şehir dışındaki (sayfiye yerlerindeki) tedavi merkezleri ve vereme karşı klinikler [Peri eksohikon therapeftirion kai antifimatikon iatreion]

\section{7-1908}

Veremle savaşta hijyen, veremden korunma, verem ve evlilik hakkında

[Peri tis igieinis en to kata tis fthiseos agona, peri ton meson pros profilaksin ap'aftis kai perifthiseos kai gamou]

Toplumda ve okuldaki fiziksel ve ruhsal yorgunluğun sinir hastalıklarına ve vereme tetikleyici neden olmasi

[He somatiki kai pneumatiki iperkoposis en te ti koinonia kai tois skholeiois os prodiathetikon aition tis te neurastheneias kai tis fthiseos]

\section{1-1912}

Okul ve kadın (eş) üzerinden veremle savaş

[Peri ton dia tou skholeiu kai tis ginaikos agonos kata tis fthiseos]

Dr. Kokolatos, CTŞ tarafından çıkarılan Gazette médicale d'Orient'dan (Şark Tıb Gazetesi) ayrı olarak, 1909'da aylık Bulletin médical de Constantinople (Dersaadet Risale-i Tıbbiyesi) dergisini yayımlamaya başladı. ${ }^{27}$ Yazılarında tüberküloz istatistiklerine de yer vererek hastalığın İstanbul'daki durumunu ayrıntılı olarak inceledi. ${ }^{28}$

Kleovulos Kokolatos'un muayenehanesi, resmi görevi, dernek çalışmaları ile dergi yayıncılığı arasında deneysel araştırmalar yapmış olması onun bir başka yönünü daha göstermesi bakımından ilginçtir. ${ }^{29}$

27 Bulletin médical de Constantinople (İstanbul), directeur-propriétaire: Dr. Cléobule C. Coccolatos, rue TarlaBachi [Tarlabaş1], No. 152, Péra [Beyoğlu].

28 C.C. Coccolatos, "Statistique de la Mortalité par la Tuberculose pulmonaire dans le Département de Constantinople," Bulletin médical de Constantinople 3, 1 (15 avril 1911): 3-5.

29 Cléobule Coccolatos, "L'action du Chlorure de Baryum sur le Cour des Poulets. Expériences personnelles sur le Cœur des Poulets au Moyen du Chlorure de Baryum (Démonstration des Propriétés rythmiques de la Pointe du Cœur au Moyen du Chlorure de Baryum)," Bulletin médical de Constantinople 3, 10 (15 janvier 1912): 101-102. Baryum klorürün tavuk kalbine etkisinin araştırıldığı bu deneylerin nerede yapıldığı belirtilmemiştir. 

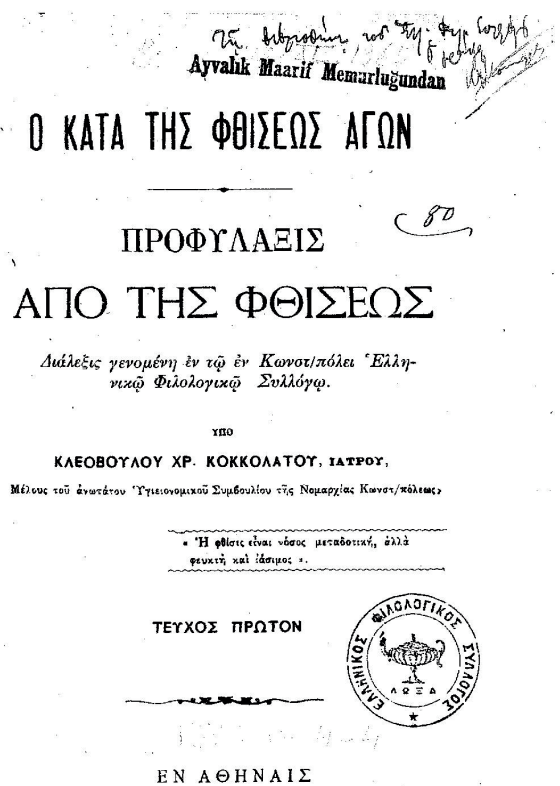

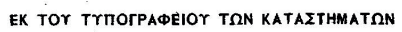

Dr. Kleovulos H. Kokolatos Veremle Savaş Veremden Korunma ${ }^{30}$

\section{BULLETIN MÉDICAL}

DE CONSTANTINOPLE

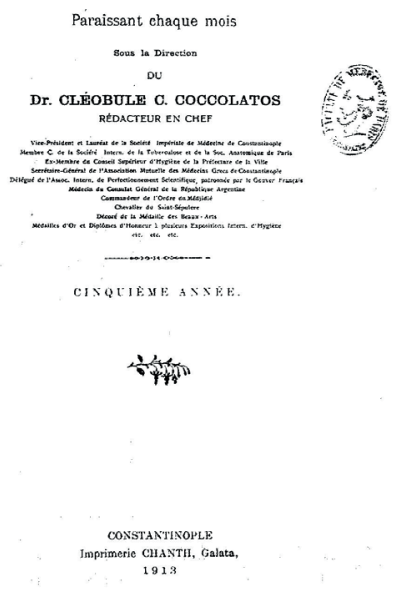

Bulletin médical de Constantinople Dr. Cléobule C. Coccolatos, rédacteur en chef

Cemiyet-i Tıbbiye-i Şahane Başkanı Dr. Antoine/Andonios E. Dallas, ${ }^{31} 1908$ başında yaptığı bir konuşmada: tüberküloz konusunda son yılların çalışmalarını özetletlerken, ${ }^{32}$

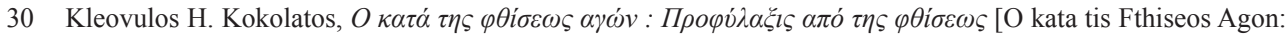
Profylaksis apo tis Fthiseos] (Atina: Anesti Konstantinidu, 1902-1903), 3 fas., 48 s. Dış kapak: sağ üstte Kokolatos imzas1, altta Ellinikos Filologikos Syllogos mühürü [Ankara MK 1973 A 1424].

31 Antoine/Andonios Emmanuil Dallas (1844-1910), CTŞ'ye 1907-1909 yıllarında iki dönem başkanlık yapmıştır, bkz. C.C. Coccolatos [Kokolatos], "Éloge du Dr. Antoine E. Dallas," Bulletin médicale de Constantinople 2, 1 (15 mars 1910): 3-6; 2, 2 (15 avril 1910): 16-18; C.C. Coccolatos, Biographie du Dr. Antoine E. Dallas. (İstanbul: Impr. Ferd. Walla, 1910).

32 M. le Président [Antoine Dallas] à propos de la ratification de la création "d'une filiale à Péra" de l'Euvre antituberculeuse de Paris, lit ce quit suit:

"Messieurs,

Il y a quelques jours le télégraphe nous a communiqué que la ratification de la création d'une filiale à Péra de l'Euvre antituberculeuse de Paris a été adoptée dans sa séance extraordinaire du 27 Février.

Cette nouvelle toute flatteuse qu'elle soit ne constitue pas une innovation pour notre pays car à côté des mesures de salubrité publique poursuivies avec assiduité de tout temps, grâce à la sollicitude d'un souverain sage et prévoyant, les données de la Science Médicale sont rigoureusement mises en pratique pour tout ce qui concerne l'hygiène non seulment de la Capitale, mais aussi de tout l'Empire Ottoman. $\mathrm{Au}$ sujet de cette question palpitante vous vous rapellez, Messieurs, qu'il y a juste, jour par jour, treize ans que Sa Majesté, l'auguste protecteur de notre Société, par message impérial transmis par l'intermédiare de S.E. feu Mavroyéni Pacha, médecin particulier de Sa Majesté, nous faisait l'honneur nous inviter à nous occuper de la question de la contagion de la tuberculose et des moyens de s'en préserver et qu'un rapport 
L'Euvre antituberculeuse de Paris adlı derneğin İstanbul'da bir şube açma isteminin takdir edilmesi gerektiğini, ancak bunun Osmanlı başkenti ve ülkesi için yenilik oluşturmayacağını; hijyen konusunun uzun süredir devletin gündeminde olduğunu belirtmiştir. Bu tarihten onüç yıl önce (8 Şubat 1895) Sultan II. Abdülhamid, Dr. Mavroyeni Paşa aracılığıyla Cemiyet-i Tıbbiye-i Şahane'nin veremin bulaşıcılığı konusunu incelemesini istemiş;, ${ }^{33}$ Cemiyetin kurduğu özel komisyonun bu konuda bir rapor hazırlamıştır. ${ }^{34}$ Raporun önerilerine uygun olarak Şişli'de Hamidiye Etfal Hastahanesi'nin bahçesinde intaniye pavyonları açılmış; Kütahya'da yapılacak yeni bir sanatoryumun projeleri geliştirilmiştir. ${ }^{35}$ Dr. Dallas, konuşmasını Dr. Kokolatos’un kurduğu “anti-tüberküloz birliği” (LCTC) ile yıllardır yaptığı çalışmalara değinerek tamamlar. ${ }^{36}$

détaillé résumant toutes les opinions émises par les Sociétaires qui avaient pris part aux délibérations fut élaboré par une Commission et soumis en Haut Lieu. Ce rapport traduit en turc a été distribué par milliers d'examples avec ordre exprès que les mesures proposées soient mises en pratiques. Les résultats de cette heureuse initiative souveraine se font sentir tous les jours; il y a un encore que Sa Majesté a décidé la création d'un Sénatorium [sic] dans un endroit bien convenable près de Kutahia dans un grande forêt de sapins. Une autre petit Sanatorium fonctionne déja comme annexe à l'Hôpital Hamidié.

Une ligue antituberculeuse aussi, la fondation de laquelle est due à un de nos distingués collègues M. le Dr. Cl. Coccolatos existe depuis quelques années, luttant dans la mesure de possible contre le terrible fléau. Tout de même, nous ne devons pas être moins heureux si d'autres confrères viennent s'unir à nous pour cette œuvre éminement solitaire."

Gazette médicale d'Orient 53, 6-7 (août et sept. 1908): 91, Séance du 28 février [de la Société impériale de médecine de Constantinople].

33 Dr. Spiridon Mavroyeni Paşa’nın çalışmaları için, bkz. Feza Günergun, "Spiridon Mavroyéni Pacha (18171902) et sa Contribution à la Diffusion des Sciences médicales dans 1'Empire Ottoman," Osmanlı Bilimi Araştırmaları 6, 1 (2004): 37-63.

34 CTŞ tüberküloz raporunu hazırlayan komisyon: Dimitri Zambako Paşa (Başkan), Edmond Lardy, Cemil [Topuzlu] (Başkan yardımcıları), Aleksandros Kamburoğlu Paşa, Dimitri Efthivuli, David Pardo, Vasil Ritzo, Pierre Apéry, Faik Paşa Della Sudda, Mihran Zartaryan ve Stavros Stamatiadis, bkz. Gazette médicale d'Orient 41, 16 (15 Octobre 1896): 233.

35 Rapor, CTŞ’nin 3 Mayıs 1895 tarihli toplantısında kabul edilmesinden yaklaşık bir buçuk yıl sonra iki bölüm halinde yayımlanmıştır. "Sur la contagiosité de la tuberculose et la manière de s'en préserver. Rapport rédigé au nom de la Société Impériale de Médecine par une commission ad hoc," Gazette médicale d'Orient 41, 16 (15 octobre 1896): 233-239); Gazette médicale d'Orient 41, 18 (15 novembre 1896: 265-272). Birinci bölümünün altbaşlığı: "Instruction pratiques sur mesures a prendre pour se préserver contre la tuberculose". Hamidiye Etfal hastanesi 1899'da açılacak, pavyonlar daha sonra yapılacaktır. .

36 Dr. Constantin Simionesco'nun l'Euvre antituberculeuse de Paris derneğinin İstanbul'da bir şube açma başvurusu ancak 1908 yılı sonunda ele alınmıştır. BOA, İ.HUS.00171.00092.001 (20 Teşirinisani 1324/9 Zilkade 1326/3 Aralik 1908):

“Verem hastalı̆̆ının men-i sirayeti zımnında Fransa'da teşekkül eden ve Memalik-i Şahane'de bir şube tesisine karar vermiş olan 'Övr dö la tüberküloz' [1'CEuvre antituberculeuse de Paris] nam cemiyetin taht-l himaye-i mülukaneye kabulü istirham kalınmıs verilen arz-ı hal bu babdaki mütalaa-yı samiye-i fehimaneleri arz buyurulmak üzre şerefsudur buyurulan irade-i seniye-i cenab-l padişahi-yi mantuk-l celile tevfikan ve lutfen suy-i sami-i cenab-ı sadaret-penahiye irsal kılınmış olmağla ol babda emr-ü-ferman Hazret-i Veli'yülemrindir."

Dr. Z.-H. Ethier'nin 1909 yılı içinde l'Euvre antituberculeuse de Constantinople için İstanbul'da çalıştığı bilgisi doğrulanamamıştır 


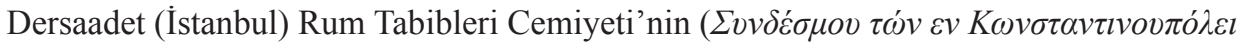

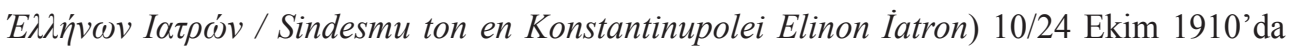
yapılan ilk genel kurulunda Dr. Aleksandros Zoiros (Çalikis) Paşa başkanlığına seçilirken, Dr. Kleovulos Kokolatos derneğin genel sekreteri olmuştur. ${ }^{37}$

Roma'da 1912 yılında toplanan 10. Uluslararası Tüberküloz Kongresi’ne yine "Meclis-i Tıbbiye-i Mülkiye azasından Zoiros [Çalikis] Paşa'nın Verem Kongresine [Congrès international contre la tuberculose, Rome, 14-20 avril 1912] ve T1b Fakültesi Hıfzıssıhha Muallimi azadan Aristidi [Skuros] Bey'in Hıfzıssıhha-yı İctimaiye Meşher-i Umumiyesine [l'Exposition internationale d'Hygiène sociale de Rome (1912), organisée à l'Occasion du Congrès international pour la Lutte contre la Tuberculose] delege" olarak gönderilmesi uygun görülmüş; ${ }^{38}$ Dr. Kleovulos Kokolatos ise kongreye kendi olanaklarıyla, derneği LCTC adına katılmıştır. ${ }^{39}$

LCTC, İkinci Meşrutiyet'in ilanından önce kurulan derneklerin çoğunluğu gibi, 1912 yılında yeniden örgütlenerek Société internationale contre la Tuberculose de Constantinople (SICTC) adını almıştır. Derneğin, Dr. Kokolatos'un sahibi ve başyazarı olduğu Bulletin médical de Constantinople dergisinde yayımlanan tüzüğü, 1903'te İstanbul'da kurulan Ligue contre la Tuberculose (Phitisie pulmonaire) de Constantinople derneğinin tüzügünün (gözden geçirilmiş) bir kopyasıdır. ${ }^{40}$ Yeni derneğin başkanı yine Kleovulos Kokolatos'dur. ${ }^{41}$

37 Şeref Etker, İkinci Meşrutiyetin Tabip Örgütleri (İstanbul: Libra Kitapçılık ve Yayıncılık, 2017), 39.

38 BOA, BEO.003894.292035.001. 3 May1s 1327/ 16 Mayıs 1911.

39 Kleovulos Kokolatos, Türkiye, Balkanlar ve Ortadoğu'daki tabip ve eczacıları Agenda Médico-pharmaceutique d'Orient illustré pour 1912 contenant les Adresses de tous les Médecins et Pharmaciens de Turquie, etc. adını verdiği bir katalogda toplamak istemiş, ancak bu yayın projesini gerçekleştirememiş̧ir.

40 Bulletin médical de Constantinople 4, 3 (15 août 1912): 39-41.

41 A. Kifides [Atanas Kifidis], "Dr. Klebül S. Kokolatos / Dr. Clébule S. Coccolatos," Türkiye Teracimi Ahval Ansiklopedisi / Encyclopédie biographique de Turquie, c. 3, haz. Mehmet Zeki [Pakalın] (İstanbul: Hamit Matbaası, 1930-1932), 469-70 (portre)."

“Tabip. İstanbul'da (Tarabya) doğmuş olan Dr. Kokolatos Veremle Mücadele Cemiyeti'nin (Ligue contre la Tuberculose) müessislerinden olup Cemiyetin eski reisidir. 1903'te Vilayet Sihhiye Meclisi (Conseil supérieur d'Hygiène) azası ve İstanbul Sıhhi Risalesi'nde (Bulletin médical de Constantinople) müdür ve başmuharrir olmuştur. İstanbul Tip Cemiyeti'nin [Cemiyet-i Tıbbiye-i Şahane] birincilik mükafatını kazanmış olan Dr. Kokolatos, Paris'teki Sosyete Anatomik (Société anatomique de Paris) ve Beynelmilel Veremle Mücadele Cemiyeti'nin (l'Association internationale contre la Tuberculose) muhabir azalığını yapmış, bilhassa andokart [endokard], miyokart [miyokard], perikart [perikard ve] İstanbul Tıp Cemiyeti'nin [CTŞ] takdirini kazanmış olan kalp nevrozlarının usülü tedavisi hakkında ve Veremle Mücadele

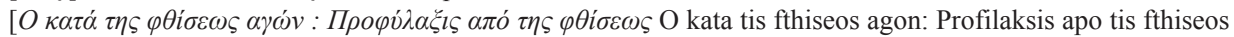
/ Veremle Savaş, Veremden Korunma] gibi birçok tetkikler neşretmiştir. "Dermatoloji faaliyetine dair raporu" ilk ellinci sene-i devriyesinin tes'idinde Tip Cemiyeti'ne takdim edilmiştir. Mumaileyh, Commandeur de la Couronne de Roumanie, Commandeur du St. Sépulcre unvanlarını haiz olup 1912 Roma Beynelmilel Veremle Mücadele Kongresinin (Dixième Conférence internationale contre la Tuberculose) altın madalyasını ihraz etmiştir.” Dr. Kokolatos, ayrıca 1905 yılında bir Sanayi Madalyası ile ödüllendirilmiştir. BOA, DH.MKT.00924.00078.001. 


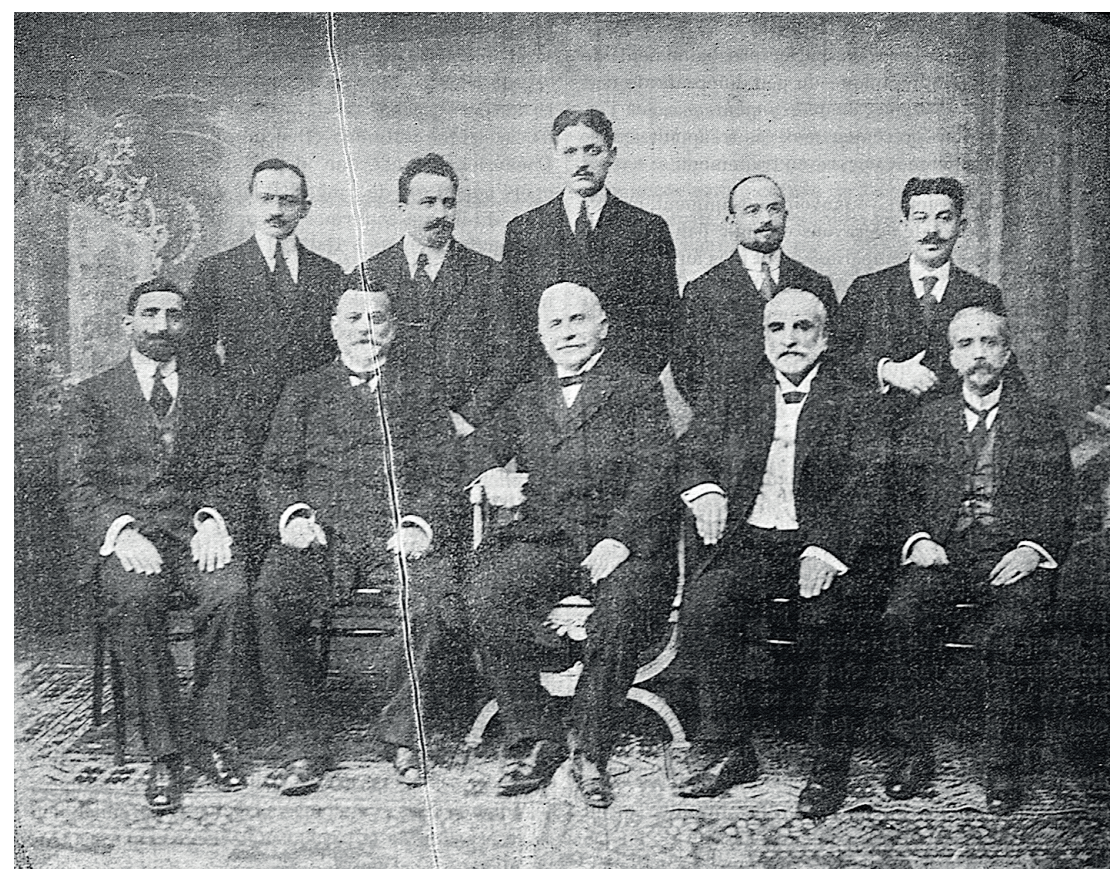

Cemiyet-i Tıbbiye-i Şahane'nin 1913-1914 dönemi Yönetim Kurulu üyesi Dr. Kleovulos Kokolatos (ön sıra, soldan ikinci) ${ }^{42}$

Dr. Kleovulos Hristos Kokolatos, 1930'lu yıllara kadar Beyoğlu’ndaki evinde hekimlik

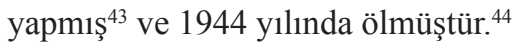

\section{Société internationale contre la Tuberculose de Constantinople}

İstanbul'da 1903 y1lında kurulan Ligue contre la Tuberculose (Phitisie pulmonaire) de Constantinople (LCTC) derneğinin adı, Meşrutiyet'in ilanından sonra, 1912'de Société internationale contre la Tuberculose de Constantinople'a (SICTC) dönüştürülmüştür. Derneğin adındaki 'Enternasyonal / Uluslararası' nitelemesi, İmparatorluğun bütün

42 Oturanlar (sağdan sola): Eczac1-kimyager Pierre Apéry (Petros Aperis), Dr. Simeon Hristoforidis, Dr. Yeorgios K. Noulis (Başkan), Dr. Kleovulos H. Kokolatos (Başkan yardımcısı), Dr. Samuel Abrevaya [Marmaralı / Abravanel]; ayaktakiler: Dr. Jak (Yako Moiz) Barbut, Dr. Vasil Konos, Dr. Vanya H. Koidan (Vania Coïdan), Dr. Aleksandros Sarandi-Pappadopulos, Dr. Dimitrios Kilaiditis. Bulletin médical de Constantinople 5, 5 (15 mars 1914): 67.

43 Kokolatos Bey, Adres: Beyoğlu, Sakızağac1 32 No. hane; Oda [İstanbul Tabip Odas1] No. 773, Üçüncü Mıntaka Etibba Odasına Mukayet Aza Cetveli, 1933 (İstanbul: T.C. 3üncü Mıntaka Etibba Odas1, 1933), 26.

44 Kleovulos H. Kokolatos'un ölüm kayıtları görülmemiştir. Ancak, 1944 yılının Mart ayı içinde ölümünün kırkıncı gününde adına İstanbul Arnavutköy'ünde bir ayin düzenlenmesi 1944 başında öldüğünü göstermektedir. Nerede öldüğü ise bilinmemektedir. "Dr. K1. Kokkolatos," erişim 15.03.2020, http://www.megarevma.net/ $\underline{\text { Ofikialoi.htm }}$ 
'millet'lerine hizmetin amaçlandığını ve üyeleri arasında "din (inanç, kült), milliyet ve cinsiyet ayrımı yapılamayacağını” (Mad. 5) vurgular. Böylece Dernek, İkinci Meşrutiyet'in 'müsavat ve uhuvvet' kavramlarını benimsemiş olmaktadır. Verem gibi, çağın yaygın ve ölümcül hastalıklarından biri söz konusu olduğunda çoğul kültürlü bir metropolün insanlarına farklı davranılması düşünülemezdi. Tüzüğe göre, Derneğin halka açık konferansları ve yayınları "ülkede konuşulan çeşitli dillerde yapılacaktır” (Mad. 4). Tüzük metninin - çağın tabipleri için lingua franca olan - Fransızca hazırlanması, LCTC'ın ilk toplantılarını Cemiyet-i Tıbbiye-i Şahane'de yapması, tabipler arasında yerleşmiş olan diyaloğun bir devamı sayılabilir. İkinci Meşrutiyet döneminde kurulan derneklerde siyaset yasaklanmışken, kurucuları SICTC tüzüğünde bu koşula din konusunun eklenmesi önemsemişlerdir (Mad. 24). ${ }^{45}$ Derneğin yabancı sağlık kuruluşları ve kurumlarıyla işbirliği yapacağı da açıklanmıştır (Mad. 3).

SICTC derneğinin tüzüğü daha önce aynı amaçla kurulan Ligue contre la Tuberculose (Phitisie pulmonaire) de Constantinople'un 1903 tarihli tüzüğünün aynıdır: Sadece dernek adından 'fitizi pulmoner' (akciğer tüberkülozu: sillü’r-rie) terimi çıkarılmıştır. ${ }^{46}$ Tüzükteki diğer değişiklik 'ambulance' (poliklinik) yerine 'dispensaire' (dispanser) sözcügüünün kullanılmasıdır. ${ }^{47}$ Tüzüğün 30. maddesinde: Birliğin mühüründe sağlık simgesi (symbole de santé) ve kuruluş tarihinin bulunacağının belirtilmesine karşın, Kokolatos’un yayımladığı metinde (ikidilli: Fransızca ve Türkçe olması gereken) bir mühür yoktur. İleride bulunacak belgelerle buna benzer eksik bilgilerin tamamlanabileceğini umuyoruz.

İttihat ve Terakki hükumetinin Bahriye Nazırı Cemal Paşa'nın girişimiyle İstanbul'da 20 Nisan 1918 tarihinde $^{48}$ kurulan Veremle Mücadele Osmanlı Cemiyeti'nin Nizamnamesinde "aynı unvan ve maksad ile başka bir cemiyet teşkil edilemez; Veremle Mücadele Osmanlı Cemiyeti Memalik-i şahanede birdir” (Mad. 3) yazılmış olması bu tarihte, VMOC'nin Société internationale contre la Tuberculose de Constantinople'un yerini almasının öngörüldüğünü düşündürmektedir. ${ }^{49}$ İki derneğin tüzükleri arasındaki benzerlikler dikkat çekicidir. Veremle Mücadele Osmanlı Cemiyeti dernek olarak bir varlık göstermemiştir: Dr. Tevfik Sağlam'a

45 Bkz. Tecemmuat Hakkında Kanun-ı Muvakkatı, 3 Mart 1328 / 16 Mart 1912.

46 LCTC Tüzügüne göre (Mad. 32) “tüzüğün yürürlük süresi üç yıldır”. Bu durumda 1906, 1909 ve 1912 yıllarında Tüzük metni gözden geçirilebilecektir. Birlik, 1912 yılında yapılan Genel Kurulunda dernek adıyla tüzük yazımındaki diğer değişiklikleri kabul etmiş olmalıdır.

47 Fitizyoloji/Ftizyoloji (mebhasü'l-sill) tüberküloz bilimi için kullanılan bir terimdir. İstanbul Üniversitesi'nde (Cerrahpaşa Hastanesi) 1951'de kurulan Ftizyoloji Kliniğinden sonra, Ankara (1952) ve Ege Üniversitelerinin Tıp Fakültelerinde (1955) Ftizyoloji Klinikleri açılmıştır. Verem Savaş Dispanseri günümüzde de kullanılan kurumsal bir isimdir.

48 "Bahriye Nazırı Cemal Paşa Hazretlerinin riyasetinde kurulmuş bulunan Veremle Mücadele Osmanl Cemiyeti, menafi-i umumiyeye hadim olduğundan 25 Mayss 1334 tarihinde irade-i Hazret-i Padişah-1 şerefsad [sic] buyurulduğundan" 8 Haziran 1334/1918 tarihinde onaylanmıştır, Gökçe, Verem Savaşında 50 Yll, 1918-1968 (İstanbul: Türkiye Ulusal Verem Savaşı Derneği, 1968), 8. 
göre, "[Umumi] harbin son zamanlarında İstanbul'da bir 'Verem Mücadele Cemiyeti' [VMOC] teşekkül etmiş, fakat harbin felaketle neticelenmesi üzerine bir şey yapmadan dağılmıştır". ${ }^{50}$ SICTC derneğinin üyeleri, Mütareke döneminde ağırlaşan sağlık sorunlarının başında gelen vereme karşı savaşım içindeki yerlerini almış olmalıdır. ${ }^{51}$

SICTC Yönetim Kurulu üyelerinin adları (şimdilik) bilinmemekle birlikte, ${ }^{52}$ İkinci Meşrutiyet'in "vatandaşları” birleştirici atmosferinde, Dernek içinde Rum, Müslüman, Ermeni, Musevi ve Frenk milletinden tabiplerin birlikte görev aldıklarını düşünüyoruz. ${ }^{53}$ Derneğin geniş tabanlı Yönetim Kurulunda (Mad. 14) toplumun her kesiminden temsilci ve danışman bulunmuş olmalıdır. VMOC'nin Merkez-i umumisi içinde, Reis-i sani olarak Dr. Besim Ömer [Akalın] Paşa ile Dr. Aleksandros Pappas'nın adlarının geçmesi, SICTC politikasına bir karşılık olarak düşünülebilir. ${ }^{54}$

Tüzükte veremle savaşımın ilke ve yöntemleri ayrıntılı olarak açıklandıktan sonra (Mad. 2), Dernek başkanının bir tabip olması ilkesi getirilmiştir (Mad. 14). Bağışçılığın tanımlandığı (Mad. 27-28) ve Yönetim Kurulu üyelerinin görevlerinin sıralandığı tüzükte, toplantıların düzeni ayrıntılı olarak açıklanmıştır. SICTC üye listeleri ile çalışma ve etkinliklerine ilişkin haber, belge ve defterler henüz bulunamamıştır. Üyeler arasında cinsiyet ayrımı

50 Tevfik Sağlam, “Türkiye verem savaşının tarihçesi” konusunda, 1918'de kurulan Veremle Mücadele Osmanlı Cemiyeti için 'Memleketimizde veremin büyük bir afet teşkil ettiği ve buna karşı savaşmak gerektiği fikrinin Birinci Cihan Harbinin son senesinde belirmeğe başladığını görüyoruz. Filhakika harbin son zamanlarında İstanbul'da bir "Verem Mücadele Cemiyeti" (sic) teşekkül etmiş, fakat harbin felaketle neticelenmesi üzerine bir şey yapmadan dağılmıştır,' demektedir, bkz., Türkiye'de Verem Savaşı, Onbirinci Milli Türk Tıp Kongresi, Ankara, 16-19 Ekim 1950, raportör Tevfik Sağlam (İstanbul, Kader Basımevi, 1950), 12. İhsan Rifat Sabar'ın benzer bir yorumu: "Memleketimizde ilk verem savaşı teşkilatı 1923'te İzmir'de kurulmuştur (Prof. Tevfik Sağlam ve Dr. Behçet Uz’un teşebbüsile) [İzmir Veremle Mücadele Cemiyet-i Hayriyesi]. Fakat fiili bir hareket gösterememiştir.” İ.R. Sabar, Tüberküloz Tarihçesi (İstanbul: İstanbul Üniversitesi Tıp Tarihi Enstitüsü Yayınları, 1956), 54.

51 Mütareke dönemine raslayan influenza (İspanyol nezlesi / Grippe espagnole) pandemisi süresince bile İstanbul'da görülen en yaygın hastalık tüberküloz (Tb) olmuştur: 1919 Tb 3.183, Grip 1.140; 1920 - Tb 3.820, Grip 3.350; 1921 - Tb 3.375, Grip 2.209, bkz. Albert Dejouany, Léopold Belbèze, Les Alliés à Constantinople: Le Service de Santé du Corps d'Occupation français, son Euvre militaire, médicale et sociale (Paris: Les Presses Universitaires de France, 1925), 66 (tablo).

52 Leonidas G. Limarakis (1854-1912) SICTC kurulmadan kısa bir süre önce ölmüştür. Dr. Limarakis 1906-1911 yıllarında Syllogos'un başkanlığını yapmış; kendisinden sonra başkanlığa Dr. Zoiros Paşa seçilmiştir. Bkz. Haris Eksertzoglou, Osmanlı'da Cemiyetler ve Rum Cemaati: Dersaadet Rum Cemiyet-i Edebiyesi, 18611912, çev. Foti Benlisoy ve Stefo Benlisoy, 1. bs. (İstanbul: Tarih Vakfı Yurt Yayınları, 1999).

53 Pierre Apéry (1852-1918) İstanbul'daki tıp ve eczacılık derneklerinin değişmez isimlerinden biridir, bkz. Michéle Nicolas, "Eczacı Pierre Apéry ve Bilimsel Yayınları," IV.Türk Eczacıllk Tarihi Toplantısı Bildirileri (45 Haziran 1998 ; İstanbul), ed. Emre Dölen (İstanbul: Marmara Üniversitesi Eczacılık Fakültesi, 2000), 125140 .

54 Veremle Mücadele Osmanlı Cemiyeti’nin ‘aza-yı müessisesi’ içinde Memalik-i Osmaniye Musevi Etibba Cemiyeti üyelerinden, Bahriye Nezareti sıhhiye müfettiş-i umumiliği üçüncü şube müdiri Dr. Viktor Bey (Galimidi, 1862-1934) de vardır. Dr. Aleksandros Pappas için, bkz., Vural Solok, "Doç.Dr. Alexander Pappas (1872-1942)," erişim 23.3.2020, https://history.uroturk.org.tr/biyografiler/doc-dr-alexander-pappas/ 
gözetilmeyeceğinin belirtilmesine ve kadınlara ayrı bir üyelik statüsü tanınmasına karşın (Mad. 5), bilindiği kadarıyla, derneğin kadın doktor üyesi olmamıştır. ${ }^{55}$

Verem, bir toplum sağlığı sorunu olarak Osmanlı halkını birinci derecede ilgilendirmektedir. Özellikle Berlin çıkışlı güncel haberler, Behring ${ }^{56}$ ve Koch'un tüberküloz çalışmaları yakından izlenmektedir. ${ }^{57}$ Hastaların, hekimler ve sağlık kuruluşları (sanatoryumlar) arasındaki hareketleri doğal bir 'ağ' oluşumuna yol açmıştır. ${ }^{58}$ Veremin sağaltılabileceği umudu hastaları, hekim ve hastaneler yanında, kendilerine yakın buldukları derneklere yöneltmiştir. İstanbul'da 1903 yılında kurulan verem savaşımı derneği bu ilginin odağına yerleşerek sözünü dinletebilmiş ve halka hastalıktan korunmanın yollarını göstermiştir. ${ }^{59}$ La Ligue contre la Tuberculose (Phitisie pulmonaire) de Constantinople, başlangıçta "pratik bilgiyi yaymaya çalışan bir akademik girişim" olarak değerlendirilmiştir. ${ }^{60}$ Derneğin, "zaman içinde sanatoryum açma” amacinı (Mad. 2) gerçekleştirememesi bir ölçüt sayılırsa, bu yorumda bir doğruluk payı olduğu söylenebilir.61 Ancak, bir dönem için Türkiye'de verem savaşımına katkılar sağladığı kuşkusuzdur.

\section{Sonuç}

İstanbul Uluslararası Verem Savaşımı Derneği Société internationale contre la Tuberculose de Constantinople'ın 1912 tarihli tüzügünün üç yıl sonra, 1915'te yapılacak bir Genel Kurulda ele alınarak güncellenmesi öngörülmüş (Mad. 32), ancak Birinci Dünya Savaşının başlaması, dernek kurullarının toplanmasını engellemiştir. Savaşın yarattığı

55 SICTC kurulduğu tarihte İstanbul'daki tek kadın hekim Dr. Amália Frisch'dir (Edirne 1882-Budapeşte 1941), bkz. László András Magyar, Şeref Etker ve Szabolcs Dobson, "Dr. Amália Frisch among Women and Wars, Istanbul to Budapest," Medicina Historica 1, 3 (2017): 163-167.

56 “Doktor [Emil von] Behring ve Verem," İkdam, numro 3330, 6 Receb 1321/15 Eylül 1319/28 Eylül efrenci 1903, s. 3, st. 1-3.

57 Gülten Dinç ve Ayten Arıkan, "The Interview with Robert Koch held by Hüseyin Hulki and the Ottoman Delegation on Tuberculin Therapy," Vaccine 37, 17 (2019): 2422-2425.

58 Dr. Giovanni B. Violi'nin 1902 yılının Temmuz ayında Burgazada'da açtığı çocuk sanatoryumu için bkz. Gülten Dinç ve Şeref Etker, "Türkiye Çocuk Hekimliğinin İlk Dergisi: La Pédiatrie en Turquie / Türkiye'de Emraz-l Etfal," Osmanll Bilimi Araştırmalarl 5, 2 (2004): 62-102. Dr. Vasil Ritzo bu derginin yayın kurulunda yer almıştır.

59 Tevfik Salim Sağlam, Askeri Tibbiye'den 1903'te mezun olmuş, 1909'da Tip Fakültesi'nin kadrosuna katılmıştır. Bu tarihlerde İstanbul'daki verem savaşımı ve sanatoryumlar konusunda bilgisinin olmaması düşünülemez. Buna karşın, "Bizde hususi sanatoryumların ilk müteşebbis ve müessisi Dr. Musa Kazım’dır. İlk sanatoryumunu 1924'de Büyükada'da bir köşkte kurmuş[tur]” yazmıştır, bkz. Tevfik Sağlam, “Tüberküloz Savaş1,” Tüberküloz. 3. İç Hastalıkları Kliniğinde Tertiplenen Olgunlaşma Kursu, yay. Tevfik Sağlam (İstanbul: Mazlum Kitabevi, 1943), 145.

60 Medical Record (New York) 65, 24 (18 Haziran 1904): 1015 (Our letter from Constantinople). Yazar, LCTC için "taklitçi" derken, doğru yönde bir çaba olduğunu kabul etmektedir: "La Ligue contre la Tuberculose (Phithisie pulmonaire) de Constantinople is an imitative effort in the right direction, though it must necessarily - and for long - be looked upon as a purely academic attempt to propagate a practical knowledge."

61 La Revue internationale de la Tuberculose (Paris) 18, 4 (Ekim 1910): 283. LCTC derneği 1910 y1lına kadar bir tüberküloz dispanseri açma olanağını da bulamamıştır: "Lutte de solidarité sanitaire engagée déjà par la Ligue anti-tuberculeuse de Constantinople. Elle aussi s'est occupée de l'installation d'un dispensaire à Péra, elle n'a pu arriver à trouver les moyens." 
yıkım, göçler ve yoksulluk tüberkülozun bütün sınıflar arasında yayılmasına neden olurken veremle savaşımı görev bilen tabipler ve gönüllüler hastalıktan korunma ve sağaltım için, toplumsal uğraşılarını sürdürmüşlerdir. 1903'te kurulan İstanbul Verem (Fitizi Pulmoner: Akciğer Tüberkülozu) Savaşımı Birliği Ligue contre la Tuberculose (phitisie pulmonaire) de Constantinople'ın üyeleri bu çalışmalarıyla yüzyılın başından Cumhuriyet'in kuruluşuna kadar verem hastalığına karşı bir siper oluşturmuşlardır. ${ }^{62}$

\section{İstanbul Uluslararası Verem Savaşımı Derneği Tüzüğ ̈̈ ${ }^{63}$ Derneğin amacına dair}

Mad. 1. İstanbul'da, veremle mücadele amaçlı bir dernek kurulmuştur. $\mathrm{Bu}$ dernek şimdilik Osmanlı İmparatorluğu'nun başkenti ve kenar mahallelerinde faaliyet gösterecektir.

Mad. 2. İstanbul [Uluslararası] Verem Savaşımı Derneği, halkı veremden korumak için vazgeçilmez olan pratik bilgileri mümkün olan her türlü yolla (toplantılarda halka açık konferanslar, üyelerinin okullarda vereceği popüler dersler, hastalıktan korunmak için halkın anlayacağı dilde pratik öğütlerin yayınlanması vs.) yayarak; hastalığa karşı bilimselliği kanıtlanmış koruyucu ve pratik tedbirleri (çoğunluğu bedava olarak okullara tükürük hokkaları; okul, eczane, toplantı mekanları ve diğer bu gibi yerlere, veremi önleyip yenmeye yönelik vazgeçilmez temel bilgileri içeren tabloların dağıtılması) doğrudan uygulayarak; başkentin özellikle kalabalık mahallelerinde, göğüs yakınması olan fakir hastalara gerekli tıbbi konsültasyon ve tedavinin bedava sağlanacağı dispanserler kurarak; yapılacak bağışlar ve üye aidatları sayesinde özellikle fakir veremlilerin tedavisi için, zaman içinde sanatoryumlar $\left(^{*}\right)$ açarak, keza bu hastalıkla mücadelenin gerektirdiği diğer her türlü yolla amacına ulaşmayı hedeflemektedir.

[* Sanatoryum ve dispanserlerle ilgili özel yönetmelikler düzenlenecektir.]

Mad. 3. Dernek, amacına ulaşmak için hem Osmanlı İmparatorluğu hem de yabancı ülkelerin dispanser, hastane ve diğer benzeri kuruluş ve tıbbi kurumlarıyla iletişime geçecektir.

Mad. 4. Derneğin halka açık konferansları, aynı zamanda her türlü yazılı̈ önleyici tedbir, ülkede konuşulan çeşitli dillerde icra edilecektir.

62 Cumhuriyet'in ilk yıllarında İstanbul'da kurulan İstanbul Verem Mücadelesi Cemiyeti (Ligue antitubeculeuse d'Istanbul) için bkz. Tevfik İsmail Gökçe, İstanbul Verem Savaşı Derneği Kuruluş, Gelişim ve Çalışmalar (1927-1971) (İstanbul: İstanbul Verem Savaş Derneği, 1972).

63 "Règlement de la Société internationale contre la Tuberculose de Constantinople," Bulletin médical de Constantinople 4, 3 (15 août 1912): 39-41. Dernek tüzüğü resmen onaylandıktan sonra yayımlanmıştır. SICTC tüzügünün Fransızca metni için bkz., Şeref Etker, İkinci Meşrutiyetin Tabip Örgütleri (İstanbul: Libra Kitapçılık ve Yayıncılık, 2017), 379-384. Bu tüzük, dernek adı dışında LCTC tüzüğünün aynıdır, bkz. yukarıda dn. 3. 


\section{Derneğin üyelerine dair}

Mad. 5. İstanbul [Uluslararası] Veremle Savaşımı Derneği, din, millet ya da cinsiyet farkı gözetmeksizin seçilen üyelerden oluşur. Üyelikler Faal (yerleşik), Muhabir ve Fahri (Hanımlara Katılımcı üye unvanı verilmiştir) olarak üçe ayrılır.

Mad. 6. Faal üyelerin görevi Derneğin amacina her türlü yolla hizmet etmektir.

Mad. 7. Faal üyeler, Dernek üyelerinden birinin yazılı talebi üzerine, aranan vasıflara sahip ve aylık 5 kuruş aidat ödeyecek kişiler arasından oylamayla seçilirler.

Mad. 8. Muhabir üyeler, Dernek üyelerinden üçünün yazılı talebi üzerine, başkent dışında ikamet eden ve Derneğin hedeflediği amaca ulaşmasına katkıda bulunabilecek kişiler arasından seçilirler.

Mad. 9. Fahri üyeler, Dernek üyelerinden üçünün yazılı talebi üzerine, veremle mücadeleye çokça katkı sağlayan kişiler arasından seçilirler.

Mad. 10. Hem Faal hem de Muhabir ve Fahri üyelerin seçimi gizli oy ve Dernek Yönetim Kurulunun toplantılarda hazır bulunan üyelerinin mutlak çoğunluğu ile gerçekleştirilir.

Mad. 11. İstanbul'da bulunan ve Derneğin meclislerine iştirak eden Fahri ve Muhabir üyeler, Yönetim Kurulu üyeliklerine seçilme hariç, Faal üyelerinkiyle aynı haklardan yararlanırlar. Bir Muhabir üye bir yıl süreyle İstanbul'da kalacak olursa, genel sekreter tarafından Faal üyeliğe geçirilir ve aylık aidat ödemek zorundadır.

Mad. 12. Dernek, üyelerinin her birine dernek mührünü taşıyan ve başkan ile genel sekreterin imzaladığı bir diploma verir, aynı zamanda yürürlükteki yönetmelikten bir örnek gönderir.

Md. 13. Yıllık aidatını seçimlerin yapıldığı güne kadar ödemeyi ihmal eden bir Faal üye seçme ve seçilme hakkını kaybeder. Ve eğer söz konusu ödemeyi izleyen yılın seçimlerine kadar ihmal edecek olur ise istifa etmiş sayılıp adı, Derneğin üye sicil defterinden silinir.

\section{Derneğin Yönetim Kuruluna dair}

Mad. 14. İstanbul [Uluslararası] Verem Savaşımı Derneği bir başkan, iki başkan vekili, bir genel sekreter, üç özel sekreter, bir muhasip, bir haznedar ve 16 müşavir üyeden oluşan 25 kişilik bir kurul (Yönetim Kurulu) tarafından yönetilir. Başkan, bir başkan vekili, bir sekreter ve altı müşavirin tıp doktoru olmaları gerekir.

Mad. 15. Başkan, hem Yönetim Kurulunu hem de Genel Kurulu olağan ve olağanüstü toplantılara çağırır. Gündeme ait tartışmaları idare eder, oturum tutanaklarını ve derneğe ait 
bütün yazıları, aynı zamanda haznedar tarafından ödenecek olan fatura ve ödeme emirlerini imzalar. Görev başında bulunamayan başkanın yerini vekillerinden biri doldurur.

Mad. 16. Genel Sekreter, Derneğin arşiv ve mühürünü, protokol ve muhaberatını muhafaza eder. Üyeleri sicil defterine kaydeder ve mukim üyelerin belli bir listesini muhasibe verir. Oturumlarda, Derneğe hitaben gönderilen yazıları okur; Derneğe ait diploma ve bütün belgeleri Başkanla birlikte mühürleyip imzalar. Kimsenin arşive ait herhangi bir nesneyi Dernek binasının dışına çıkarmasına izin vermez ve isteyene sekretarya ile ilgili her türlü bilgiyi sağlar.

Mad. 17. Özel sekreterler [oturum sekreterleri], Yönetim Kurulunun her bir oturumunun tutanaklarını uygun bir kütüğe kaydederler. Bunları bir sonraki oturumun başında okur ve tutanaklar kabul edildiğinde Başkanla birlikte imzalarlar. Aynı zamanda Genel kurulların tutanaklarını kaleme alırlar.

Mad. 18. Haznedar (Veznedar), Derneğin kasasını tutar. Kendisine yatırılan her bir meblağdan şahsen sorumludur. Aidatların muhasip tarafından verilen ve bizzat imzaladığ çift makbuzlarla zamanında tahsilini gözetir. Başkanın izni olmaksızın kendi başına hiçbir harcamada bulunmaz. Üzerinde yalnızca, Dernek adına en fazla 20 lira bulundurabilir.

Mad. 19. Muhasip, sicil defterine göre üye aidatlarının makbuzlarını çift olarak tanzim eder ve tahsili için Veznedara iletir. Ödeme emirlerini de aynı şekilde haznedara gönderir. Bunları imzaladıktan sonra Başkanın da imzasına sunar ve özel bir muhasebe defterine kaydeder.

Mad. 20. Yönetim Kurulu üyeleri genel olarak Derneğin gelişimini, aynı zamanda mali durumunu gözetirler. Ayda bir kez düzenli ya da Başkanın davetiyle olağanüstü olarak toplanır ve Derneği ilgilendiren her konuda görüşüp karar verirler. Yönetim Kurulunun gerekçesiz peşpeşe üç oturumuna katılmayan her üyesi istifa etmiş sayılır ve yerini söz konusu meclisin izleyen oturumunda tayin edilen bir üye alır.

\section{Derneğin oturumlarına dair}

Mad. 21. Dernek, Yönetim Kurulunun olağan ve olağanüstü oturumları dışında, yılda bir kez olağan Genel Kurul çağrısı yapar ve Başkanın gerekli gördüğü durumlarda başka olağanüstü oturumlar gerçekleştirir.

Mad. 22. Yönetim Kurulu, bir oturumdaki hazır üyelerin sayısı ne olursa olsun, Başkan ve Başkan vekillerinden birinin hazır bulunması şartıyla toplantı yeter sayısını bulmuş sayılır.

Mad. 23. Bir oturumda hazır bulunan bütün üyeler adlarını bir katılım defterine kaydederler. 
Mad. 24. Oturumlar süresince siyaset ve dinden bahsetmek yasaktır.

Mad. 25. Her üyenin, görüşmeler sırasında aynı konu üzerinde en fazla iki kez söz söyleme hakkı vardır. Son söz tartışma konusunu ortaya atan kişiye verilir. Bununla beraber üç kezden fazla söz verme hakkı Başkana tanınmıştır.

Mad. 26. Oyların [eşit] dağılımı durumunda Başkanın oyu, hem Yönetim Kurulunun hem de Derneğin oturumları sırasında iki oy değerinde sayılır.

\section{Derneğin katılımeı, bağış̧̧ı ve hayırseverlerine dair}

Mad. 27. Derneğe yılda en az bir mecidiye yatıran her şahıs Katılımcı [souscripteur] sayılır.

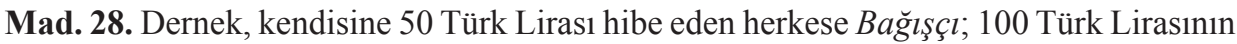
üzerinde bir meblağı verenlere Büyük Bă̆ış̧̧ı unvanı verir. 500 Türk Lirası üzerinde para bağışlayanlar Hayırsever, 1000 Türk Lirasından çok bağışta bulunanlar ise Büyük Hayırsever ilan edilirler.

Mad. 29. Derneğe olağanüstü hizmetlerde bulunanlara Olağanüstü Şeref payeleri verilir.

\section{Derneğin mührü ve seçimlerine dair}

Mad. 30. Derneğin Société internationale contre la Tuberculose de Constantinople (İstanbul Uluslararası Verem Savaşımı Derneği) başlıklı özel bir mühürü vardır.

Mad. 31. Her yıl Mart ayının ilk Pazar günü Dernek üyelerinin Genel Kurulu toplanır. Yönetim Kurulunun başkanı bu kurulda geçmiş yılın işlerinin hesabını verir. Derneğin mali durumunu inceleme amacıyla seçilen üç üyeli bir komisyon çalışmalarının sonuçlarını ona ibraz eder. Yönetim Kurulu üyelerinin seçimi de bu oturum sırasında gerçekleştirilir.

\section{Tüzüğün elden geçirilmesine dair}

Mad. 32. İşbu tüzüğün yürürlük süresi üç yıldır. Bu süre sona erdiğinde Dernek, yarısı Yönetim Kurulundan olan üyelerinin yazılı talebiyle tüzügün yeniden elden geçirilmesini onaylar ve yeni bir tüzüğün yazılması amacıyla bir komisyon seçer. Yeni tüzük, Dernek tarafından onaylanmak üzere Genel Kurula sunulduktan sonra özel bir fasikül halinde basılır.

Hakem Değerlendirmesi: Dış bağımsız.

Çıkar Çatışması: Yazar çıkar çatışması bildirmemiştir.

Finansal Destek: Yazar bu çalışma için finansal destek almadığını beyan etmiştir.

Peer-review: Externally peer-reviewed.

Conflict of Interest: The author has no conflict of interest to declare.

Grant Support: The author declared that this study has received no financial support. 


\section{Teşekkür}

Dr. K.H. Kokolatos'un yaşamöyküsünün aydınlatılması ve yayınlarının saptanmasındaki yardımları için Panagiotis Lazos, M.Sc. (Atina), Prof.Dr. İrini Dimitriyadis (Bahçeşehir Üniversitesi, İstanbul), Theodoros Kyrkudis, M.Sc. (Aleksandrupolis) ve sayın Yani Paisios'a (Rahmetli Peder Meletios Sakulidis Kütüphanesi, İstanbul); Fransızca tüzüğün çevirisi için Tomas Terziyan, M.Sc.'a teşekkür ederim.

\section{KAYNAKÇA / BIBLIOGRAPHY}

\section{Arşiv kaynakları / Archival Sources}

Atina Üniversitesi Arşivi

T. C. Cumhurbaşkanlı̆̆ Devlet Arşivleri Başkanlı̆̆ı Osmanlı Arşivi (BOA)

BOA. İ.ŞE.00014.00037.001. Teşrinisani 1317/20 Kasım 1901.

BOA. İ.HUS.00171.00092.001. 20 Teşirinisani 1324/9 Zilkade 1326/3 Aralık 1908.

BOA. BEO.003894.292035.001. 3 May1s 1327 / 16 May1s 1911.

BOA. DH.MKT.00924.00078.001.

\section{Süreli yayınlar / Periodicals}

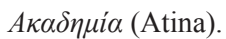

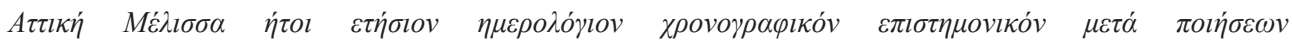

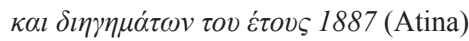

Bulletin médical de Constantinople (İstanbul)

Bulletin officiel de l'Exposition de Lyon, universelle, internationale et coloniale (Lyon)

Gazette médicale d'Orient (İstanbul)

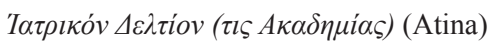

İkdam (İstanbul)

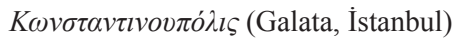

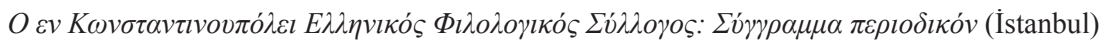

Malumat (İstanbul)

Medical Record (New York)

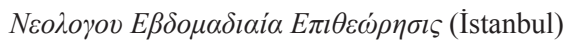

La Revue internationale de la Tuberculose (Paris)

Revue médico-pharmaceutique (İstanbul).

Sabah (İstanbul) 


\section{Basılı Kaynaklar / Printed Sources}

Aksu, Murat. "Tıp Tarihi Açısından Türkiye'de Veremle Savaş". Tıpta Uzmanlık Tezi, Ankara Üniversitesi, 2006.

Aksu, Murat. Tip Tarihi Açısından Türkiye'de Verem Savaşı. Ankara: Türkiye Ulusal Verem Savaşı Dernekleri Federasyonu, 2007.

Aksu, Murat ve Sadık Toprak. "The Importance of Associations in the Struggle against Tuberculosis in Turkey.” Tüberküloz ve Toraks 60, 3 (2012): 291-294.

Bengiserp, Saim Polat. "Türkiye'de Sanatoryum ve Gögüs Hastalıkları Hastanelerinin Tarihine bir Bakış." IV. Türk Tıp Tarihi Kongresi, Istanbul, 18-20 Eylül 1996, Kongreye Sunulan Bildiriler içinde 157-186. Ankara: Türk Tarih Kurumu, 2003.

Coccolatos, Cléobule C. "Rapport sur les Travaux de Dermatologie présentés à la Société Impériale de Médecine pendant son premier Cinquantenaire (1856-1906)." Dersaadet Cemiyet-i Tibbiye-i Şahane'nin Ellinci Sene-i Devriyesi (1856-1906) / Cinquantenaire de la Société Impériale de Médecine de Constantinople (1856-1906) içinde 191-235. Constantinople : Imp. L. Babok \& Fils, 1907.

Coccolatos, [C.C.] "Éloge du Dr. Antoine E. Dallas [I]." Bulletin médicale de Constantinople 2, 1 (15 mars 1910): 3-6.

Coccolatos, [C.C.] “Éloge du Dr. Antoine E. Dallas [II].” Bulletin médicale de Constantinople 2, 2 (15 avril 1910): 16-18.

Coccolatos, C.C. Biographie du Dr. Antoine E. Dallas. Istanbul : Impr. Ferd. Walla, 1910.

Coccolatos, C.C. "Statistique de la Mortalité par la Tuberculose pulmonaire dans le Département de Constantinople." Bulletin médical de Constantinople 3, 1 (15 avril 1911): 3-5.

Coccolatos, Cléobule. "L'Action du Chlorure de Baryum sur le Cœur des Poulets." Bulletin médical de Constantinople 3, 10 (15 janvier 1912): 101-102.

Coccolatos, Cléobule Ch. Historique de la Bibliothéque de la Société Impériale de Médecine de Constantinople, 1857-1913. Istanbul: Imprimerie Chanth, 1913.

Dallas, Antoine. "Séance du 28 février [de la Société impériale de Médecine de Constantinople])." Gazette médicale d'Orient 53, 6-7 (août et septembre 1908): 91.

Delmaire, Léa. "Construction et Déconstructions d'une Maladie sociale. Les Politiques de Lutte contre la Tuberculose en Turquie (1948-1960).” Yüksek Lisans tezi, Institut d'Études Politiques de Paris, 2017.

Dejouany, Albert ve Léopold Belbèze. Les Alliés à Constantinople: Le Service de Santé du Corps d'Occupation française, son Euvre militaire, médicale et sociale. Paris: Les Presses Universitaires de France, 1925.

Dinç, Gülten ve Şeref Etker. "Türkiye Çocuk Hekimliğinin İlk Dergisi: La Pédiatrie en Turquie / Türkiye'de Emraz-ı Etfal." Osmanlı Bilimi Araştırmaları 5, 2 (2004): 62-102.

Dinç, Gülten ve Ayten Arıkan. "The Interview with Robert Koch held by Hüseyin Hulki and the Ottoman Delegation on Tuberculin Therapy." Vaccine 37, 17 (2019): 2422-2425.

Eksertzoglou, Haris. Osmanli'da Cemiyetler ve Rum Cemaati: Dersaadet Rum Cemiyet-i Edebiyesi, 18611912. Çeviren Foti Benlisoy ve Stefo Benlisoy, 1. bs. İstanbul: Tarih Vakfı Yurt Yayınları, 1999.

Etker, Şeref. İkinci Meşrutiyetin Tabip Örgütleri. İstanbul: Libra Kitapç1lık ve Yayınc1lık, 2017.

Gökçe, Tevfik İsmail. Verem Savaşında 50 Yll, 1918-1968. İstanbul: Türkiye Ulusal Verem Savaşı Derneği, 1968.

Gökçe, Tevfik İsmail. İstanbul Verem Savaşı Derneği Kuruluş, Gelişsim ve Çalışmalar (1927-1971). İstanbul: 
İstanbul Verem Savaş Derneği, 1972.

Günergun, Feza. "Spiridon Mavroyéni Pacha (1817-1902) et sa Contribution à la Diffusion des Sciences médicales dans l'Empire ottoman." Osmanlı Bilimi Araşstırmaları 6, 1(2004): 37-63.

Hüsameddin Şerif [Kural]. Verem Teşhis ve Tedavisi. [İstanbul]: Mekteb-i Tıbbiye-i Şahane Matbaası, 1337/1921.

İlikan (Rasimoğlu), Ceren Gülser. "Tuberculosis, Medicine and Politics: Public Health in the Early Republican Turkey.” Yüksek Lisans Tezi, Boğaziçi Üniversitesi, 2006.

Kifidis A. [Atanas]. "Dr. Klebül S. Kokolatos / Dr. Clébule S. Coccolatos." Türkiye Teracimi Ahval Ansiklopedisi / Encyclopédie biographique de Turquie. 3: 469-70. Hazırlayan Mehmet Zeki [Pakalın]. İstanbul: Hamit Matbaas1, 1930-1932.

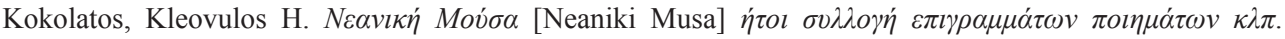
İstanbul: Patrikhane Matbaas1, 1885.

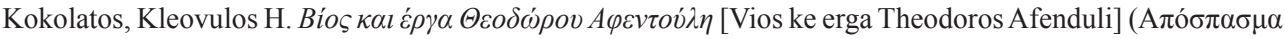

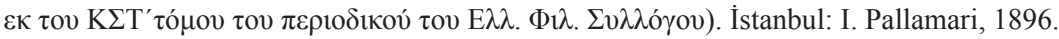

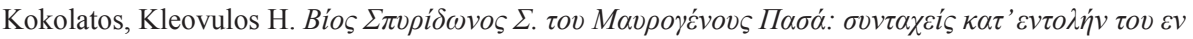

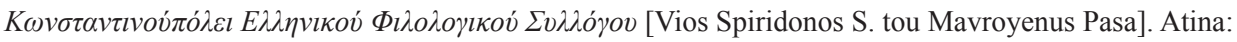
Anesti Konstantinidi, 1902.

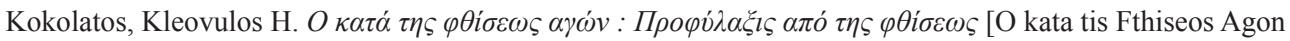
: Profylaksis apo tis Fthiseos]. Atina: Anesti Konstantinidu, 1902-1903.

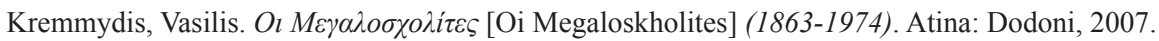

Magyar, László András, Şeref Etker ve Szabolcs Dobson. "Dr. Amália Frisch among Women and Wars, Istanbul to Budapest." Medicina Historica 1, 3 (2017): 163-167.

Nicolas, Michèle. "Eczacı Pierre Apéry ve Bilimsel Yayınları." IV.Türk Eczacllık Tarihi Toplantısı Bildirileri (45 Haziran 1998 ; İstanbul). Editör Emre Dölen içinde 125-140. İstanbul: Marmara Üniversitesi Eczacıllk Fakültesi, 2000.

"Règlement de la Ligue contre la Tuberculose (Phitisie pulmonaire) de Constantinople (14/27 Septembre 1903)." Revue médico-pharmaceutique (Istanbul) 17 (1904): 42-44.

"Règlement de la Société internationale contre la Tuberculose de Constantinople." Bulletin médical de Constantinople 4, 3 (15 août 1912): 39-41.

Sabar, İhsan Rifat. Tüberküloz Tarihçesi. İstanbul, İstanbul Üniversitesi Tıp Tarihi Enstitüsü Yayınları, 1956.

Sağlam, Tevfik. Tüberküloz. 3. İ̧ Hastalıkları Kliniğinde Tertiplenen Olgunlaşma Kursu. Yayınlayan Tevfik Sağlam. İstanbul: Mazlum Kitabevi, 1943.

Sağlam, Tevfik. Türkiye'de Verem Savaşı, Onbirinci Milli Türk Tip Kongresi, Ankara, 16-19 Ekim 1950. Raportör Tevfik Sağlam. İstanbul: Kader Basımevi, 1950.

Tecemmuat Hakkında Kanun-ı Muvakkatı. 3 Mart 1328 / 16 Mart 1912.

Tezcan, Asuman. “Savaş Yıllarında İstanbul ve Anadolu'da Verem.” Bilgi ve Bellek say1 5 (Kış 2006): 105-121.

Türkiye Teracimi Ahval Ansiklopedisi / Encyclopédie biographique de Turquie, c.II. Hazırlayan Mehmet Zeki [Pakalın]. İstanbul: Ekspres Matbaası, 1929.

Unat, Ekrem Kadri. "Osmanlı İmparatorluğunun son 40 Yılında Türkiye’nin Tüberküloz Tarihçesi Üzerine.” [İstanbul Üniversitesi] Cerrahpaşa Tıp Fakültesi Dergisi 10, 4 (1979): 273-284. 
Ü̧̧üncü Mıntaka Etibba Odasına Mukayet Aza Cetveli, 1933. İstanbul: T.C. 3üncü Mınataka Etibba Odası, 1933.

Veremle Mücadele Osmanlı Cemiyeti Nizamname-i Esasisi. [İstanbul]: Bahriye Matbaas1, 1918/1334.

Yıldırım, Nuran. “Osmanlı Devleti’nde Göğüs Hastalıkları ve Verem.” Türk Gögüus Hastalıkları Tarihi. Editör Muzaffer Metintaş içinde 35-36. İstanbul: Türk Toraks Derneği, Aves Yayıncılık, 2012.

Yıldırım, Nuran ve Mahmut. Gürgan. "Verem Mücadele Cemiyetleri/Verem Savaş Dernekleri.” Türk Gögüus Hastalıkları Tarihi. Editör Muzaffer Metintaş içinde 85-100. İstanbul: Türk Toraks Derneği, Aves Yayınc1lik, 2012.

\section{Elektronik kaynaklar / Electronic sources}

“Dr. Kl. Kokkolatos.” Erişim 15.03.2020. http://www.megarevma.net/Ofikialoi.htm

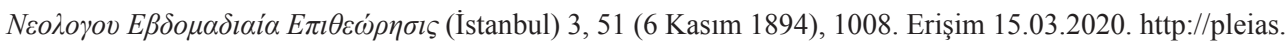
lis.upatras.gr/index.php/neologou/article/view/28574/28557

Solok, Vural. "Doç.Dr. Alexander Pappas (1872-1942).” Erişim 23.03.2020. https://history.uroturk.org.tr/ biyografiler/doc-dr-alexander-pappas/ 
